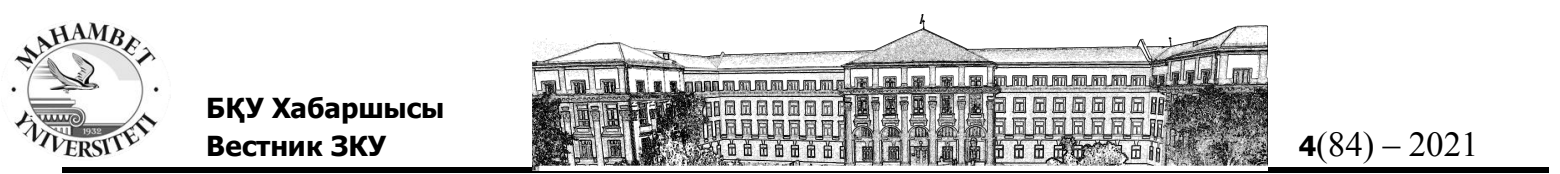

UDC 631.4

IRSTI 68.05 .45

DOI 10.37238/1680-0761.2021.84(4).52

\author{
${ }^{1}$ Kaczmarek Stawomir* ${ }^{2}$ Marquardt Tomasz
${ }^{1,2}$ Kazimierz Wielki University, Bydgoszcz, Poland
*Correspondence: slawkacz@ukw.edu.pl

E-mail: slawkacz@ukw.edu.pl, tmarq@ukw.edu.pl

\title{
SOIL MICROARTHROPODS - BIODIVERSITY, ECOSYSTEM SERVICES AND IMPACT ON HUMAN ECONOMY AND HEALTH
}

Annotation. The soil system, as a part of terrestrial ecosystems, is a place of crucial ecological processes that ensure the continuum of biological processes on Earth. The soil microarthropods are very diverse in terms of form and function, depend on the soil type, and influence the soil processes mainly through feeding, thus directly or indirectly influence the dead organic matter decomposition. Particular groups of soil microarthropods provide important ecosystem services; however, can have both positive and negative ecological and economical effects. In this paper we discussed the role of particular soil microarthropods in the context of their position within the soil food web, and other non-trophic influences on the soil ecosystem, humaneconomy and health. We also emphasized the possibilities of practical use of soil fauna.

Keywords: microarthropods, soil environment, edaphone, soil food web, organic matter decomposition.

\section{Introduction}

\section{Soil - function, factors and humus types}

In terrestrial ecosystems, the soil environment is the place of important processes of dead organic matter decomposition. When organisms die, their tissues (mostly) are deposited on the soil surface, where the various groups of decomposers start the process called mineralization. This phenomenon allows the matter and energy to circulate and, in fact, ensures the continuation of biological processes on earth.Nutrient cycling is one of the main ecosystem services provided by soil [1-6].

The soil life is extremely diverse: fungi, bacteria, protists, turbellarians, nematodes, rotifers, annelids and many various microarthropods. All these groups are linked directly or indirectly to dead organic matter and, therefore, most of them inhabit the soil level of accumulation i.e. litter and humus on the soil surface and the surface of plant roots in the belowground part. This phenomenon is called the vertical differentiation of soil life i.e. the uneven vertical distribution of organisms within the soil profile.

There are many environmental factors that influence the soil life e.g. temperature, humidity and the soil $\mathrm{pH}$. The latter is dependent on the soil chemical characteristics, mainly the parent material, however other processes influence the soil acidity e.g. rainfall and leaching, organic matter decay, plant feeding or the use of nitrogen fertilizers. Forest ecologists distinguish three main types of humus: mor, moder and mull, and the extreme types are formed in acid and alkaline soils respectively. These differences of acidity lead to formation of the so-called overlaying humus in mor-type, which is not observed in the mull-type. Moreover, type of the humus influences the bioavailability of heavy metals and, as a result, the soil toxicity [7]. Types of forest humus differ with regard to bacterial/fungal populations, the former being very rich and the latter reduced in mull humus, which is opposite in mor-type. In general, the groups of organisms differ between humus- 




types with regard to their importance e.g mites and springtails are the most important groups in mor- and moder-types while in mull-humus the importance of annelids is much higher than that of mites.

\section{Soil microarthropods}

Within the soil microarthropod communities the following systematic groups are represented: woodlice (soil crustaceans), myriapods (millipedes and centipedes), hexapods (Ectognatha: Collembola, Protura and Diplura, as well as Entognatha: Insecta) and arachnids (i.a. spiders, pseudoscorpions, harvestmen and mites).

Soil crustaceans are represented by species from the order Isopoda. Fauna of isopods differ between mor- and mull-humus types because species differ with regard to preferences to calcium content. They are not able to dig soil corridors and mainly feed on dead organic matter; however, some of them can damage tissues of living plants. They impact the organic matter decomposition by grinding the moist litter, especially in deciduous forests [3].

Soil myriapods are represented by two classes: Chilopoda (centipedes) and Diplopoda (millipedes), mainly found in moist soils of deciduous forests, rich in calcium compounds. Diplopods are rather slow-moving and predominantly detritivorous, while chilopods are fastmoving venomous predators [3].

Collembola (springtails), Protura (coneheads) and Diplura (two-pronged bristletails) form a monophyletic class Entognatha (possess internal mouthparts) that is considered as a sister group to the remaining hexapods, which belong to class Ectognatha (possess external mouthparts); however, evolutionary relationships within Hexapoda s. lato are still discussed [8,9]. Springtails are omnivorous and feed on fungi, plant debris and dead animal tissues; however, some can feed on pupae of insects, nematodes and other collembolans [3, 10]. Proturans remain one of the less known hexapods, especially from a biogeographical, ecological and systematic viewpoint - this group of the soil dwellers feed on fungal hyphae [11]. Also, the other order of basal Hexpoda, Diplura, is relatively poorly represented in the scientific literature. Two-pronged bristletails can play a role of primary consumers by feeding on plant roots; however, can also be secondary and tertiary consumers and even top predators [12].

The soil ecosystem is also habitat for many taxa of insects. Some of them are true (permanent) soil residents (geobionts) and spend their whole life (all developmental stages) within the soil profile. Other insects are geophiles, which means that they live in the soil only as immature stages e.g. white or yellow grubs (C-shaped immature forms of scarab beetles -Coleoptera: fam. Scarabeidae), wireworms (elongated, cylindrical soil-dwelling larvae of click beetles -fam. Elateridae) andelongated and flattened campodeiform (staphyliniform) larvae of roove beetles (fam. Staphylinidae). The feeding habits of roove beetles' larvae are poorly known, some of them are predators, others were found to be parasitic and others are probably scavengers [13]. Scarabeidae are represented by two feeding groups, one in which larvae feed on carion and dung, and other that feed on plant roots and decaying wood. Larval forms of Elateridae are significant root feeders and can be pests of crops.

Another, apart from beetles, group of insects that live in the soil are ants and soil-dwelling wasps (order Hymenoptera). Soil ants belong to different trophic levels (e.g leaf-cutters as primary and predators as secondary consumers); however, all are considered as "ecosystem engineers" because influence directly and indirectly on the energy flow, soil structure and habitats of other organisms [14,3]. Many species of solitary wasps and some of social wasps (superfam. Vespoidea) prepare their nests within the soil. Also,many species of true flies (order Diptera) are geophilic adults live in the above-ground habitats while their offspring pupate in the soil. Larvae of flies are very diverse in terms of feeding - their food differ from those of adults. Larval forms of Diptera are primary and secondary consumers, including ecto- and endoparasites [15]. 


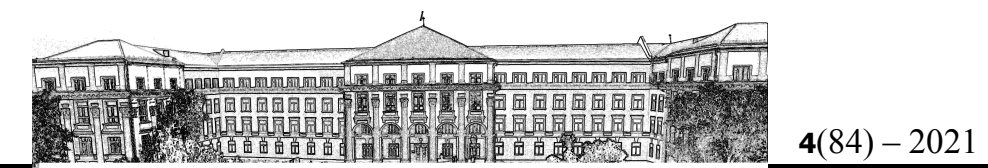

The following groups of arachnids inhabit the soil ecosystem: spiders (Araneae), pseudoscorpions (Pseudoscorpionida), harvestmen (Opilionida)and mites (Parasitiformes and Acariformes).

Spiders, as most of others arachnids, are predators - about $85 \%$ of the spider fauna overwinter in soil, mainly in leaf litter [16]. Pseudoscorpions alsoparalyze their prey with venom produced in glands that are present in one or both of cheliceral fingers in most of families [17]. Diet of Opiliones is much broader than that of other arachnids-they are predators, scavengers and detritivores. Unlike other arachnids the harvestmen can ingest solid food particles. Species that occur deeper in soil possess shorter legs when compared with the above-ground taxa [18].

\section{Soil - empire of mites}

Mites are the most diverse arachnids with regard to biology, ecology and morphology. This group is also the richest when the number of species is considered. According to Dunlop and Penney [19] there are 43,567 known species of spiders (49,773 according to World Spider Catalog [20], while there are 54,483 of mite species according to Beaulieu et al. [21], Schatz et al. [22], Walter et al. [23] and Zhang et al. [24]. Moreover, estimates of the actual number of mite species vary from 500,000 to $1,000,000$ [25].

Mites have evolved far beyond saprophagy and predation - they can feed also on plants, bacteria and fungi, and many of them are symbionts of vertebrates and invertebrates [26]. They colonized terrestrial, marine and aquatic habitats and are found in a wide range of environmental and ecological conditions; however, the soil can be called the empire of mites [25]. The forest humus type influences the communities of soil mites same as for the other above-mentioned soil groups of fauna. The density of mite communities per square meters often is measured in thousands, and densities exceeding hundred of thousands are not surprising. The impact of soil mites on the decomposition processes is a result of their feeding i.e. crumbling the detritus and preying on decomposers (saprophagous mites or other detritivores including microorganisms). The other impact of mites on the dead organic matter decomposition is the effect of their high density which allow them to effectively spread (vectoring) propagules of the soil microbiota i.e. bacteria and fungi. This kind of dispersing of microorganisms by mites is possible through carrying them on the body surface but also transporting them during digestion and depositing in other place as fecal pellets. Mites can also act as herbivores. Many mites that live on the surface of root systems feed on dead root tissues, however, some of them can feed on living roots of plants.Many Oribatida feed on lichens and algae so acting as herbivores and therefore impact on the primary production. The primary production can be also influenced indirectly e.g by feeding on saprotrophic fungi that compete with ectomycorrhizal fungi, and therefore providing better conditions for ectomycorrhiza and, consequently for plants [27, 28].

Together with springtails, the oribatid mites (moss mites) mediate fertilization between spatially separated male and female mosses [29]. Moreover, it has been found, that both groups of microarthropods preferred fertile moss shoots over sterile ones, and the possible cause is that fertile shoots secrete some substances (e.g. carbohydrates) that, as a food, attract mites and springtails. Consequently, the mutualistic relationship between microarthropods and bryophytes has been proposed, as equivalent to the above-ground plant-insect symbiosis, and as possible step of evolution animal-mediated fertlization.In the soil, three ecological groups can be distinguished: saprophagous mites dominated by taxa from the suborder Oribatida (superorder Acariformes, order Sarcoptifores);mycophagous and bacterivorous mites from the suborder Prostigmata (e.g. families Eupodina and Tarsonemina within superorder Acariformes, order Trombidiformes) and order Mesostigmata (some species from the cohort Uropodina within suborder Monogynaspida and superorder Parasitiformes) and predatory mites from Prostigmata and Mesostigmata. While saprophagous mites influence the decomposition processes directly, other groups regulate it indirectly. Predatory soil mites feed on other groups of soil fauna, including other mites [30]. Species from family Veigaiidae are assumed to be effective predators of collembola; Rhodacaridae, 

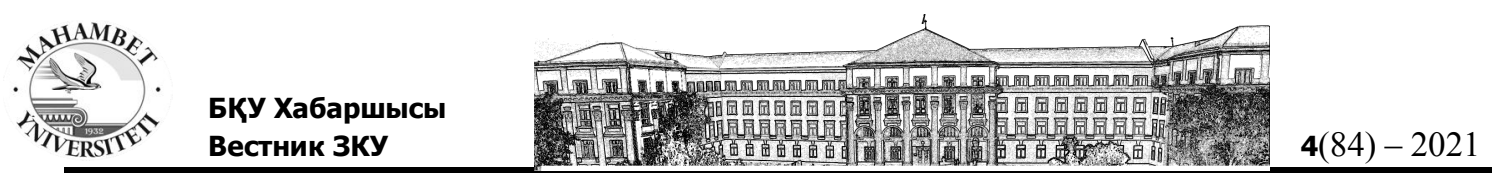

Zerconidae and Ascidae are mainly nematophagous while polyphagous Parasitidae feed on various soil faunal groups including mites [27, 31]. Preying on saprophagous oribatid mites, considering usual domination of this order within soil mite communities (Oribatida often account for $90 \%$ of community or more) has serious indirect effect on decomposition, strengthened by feeding of polyphagous predators on other saprophages e.g. springtails. Most of oribatid mites are heavily armored as adults - they are hunted mainly by large predators; however, smaller and weaker predators can also influence communities of Oribatida by preying on their eggs and less sclerotized juvenile stages [32-35].

\section{Soil microarthropods and human economy and health}

First of all, the role of soil microarthropods is expressed through their feeding. Their contribution to dead organic matter decomposition and, therefore, nutrient cycling, is essential from the point of view of the functioning of primary production - in an economic context - the plant cultivation. On the other hand, predatory microarthropods provide the natural biological control of pests (including some of the microarthropods and other animal groups e.g. nematodes). Some of the soil inhabiting mites are important pests of plant bulbs e.g. astigmatid mites (cohort Astigmatina within Oribatida). Astigmatid Tyrophagusputrescentie is serious pest of edible mushrooms e.g. Agaricusbisporus (button mushroom) or Pleurotusostraeus (oyster mushroom), feeding on both mycelium and fruiting bodies [27, 36].

The soil ecosystem is crucial also for predators that hunt their pest prey in the above-ground habitats - soil is e.g the overwintering habitat for some predaceous phytoseiid mites (fam. Phytoseiidaewithin Mesostigmata) that are important biological control agents of plant-feeding mites i.e spider mites (fam. Tetranychidae) and gall mites (fam. Eriophyidae) [37]. Pests from families Tetranychidae and Eriophyidae, except that they feed on plants, transmit bacterial and viral diseases of plants [38, 39].

Many of ticks (order Ixodida; obligatory hematophagous parasitic mites from the superorder Parasitiformes) in factspend only short time of their life associated with their vertebrate hosts (including humans) - the remaining time live e.g. in soil [40, 41]. About 130 species of Oribatidai.a.Liebstadiasimilis, Platynothruspeltifer and Adoristesovatus, transmit cestodes (fam. Anoplocephalidae) e.g. Moniezjaexpansa, AnopIocephalaperfoliata and Cittotaeniactenoides, thus being an important link in the development cycle of parasites of sheep (Ovisaries), horse (Equus caballus) and cattle (Bos taurus) [42, 27, 26].

Soil mites can be also used practically for the assessment of environment quality. Several types of habitats were studied and some of soil mite species proved to be indicators of both anthropogenic and natural environmental factors [43-50]; however, their use in ecotoxicological testing is still developing [51]. There are also important contributions to discover the significance of some soil environments which can be considered as refugia of predatory species within agricultural landscape, providing better, natural control of pests of crops [52, 53, 47].

The economic values, both benefits and losses, of insectifluence are generally well known, publicly appreciated and estimated, and their potential change, parallel to climate change, is analyzed [54-56]. The below-ground processes are equally important and interlinked with the above-ground habitats, and their economic value is also evaluated; however, with less emphasis when compared with studies on insect pollinators and pests [57-58].

\section{REFERENCES}

[1] Freckman D.W., Blackburn T.H., Brussaard L., Hutchings P., Palmer M.A. \& Snelgrove P.V.R. (1997) Linking biodiversity and ecosystem functioning of soils and sediments. Ambio 26: 556-562. [in English]. 

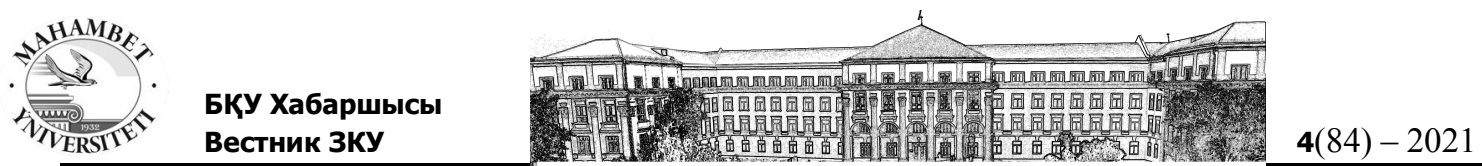

[2] Behan-Pelletier V. \& Newton G. (1999) Linking soil biodiversity and ecosystem function. The taxonomic dilemma. BioScience 49: 149-153. https://doi.org/10.2307/1313540 [in English].

[3] Coleman D.C., Crossley D.A. \& Hendrix P.F. (2004) Fundamentals of soil ecology. 2nd ed., Elsevier Inc. 386 pp. [in English].

[4] Coleman D.C. (2008) From peds to paradoxes: Linkages between soil biota and their influences on ecological processes. Soil Biology and Biochemistry 40: 271-289. https://doi.org/10.1016/j.soilbio.2007.08.005 [in English].

[5] Wall D.H., Bardgett R.D. \& Kelly E.F. (2010) Biodiversity in the dark. Nature Geoscience 3: 297-298.https://doi.org/10.1038/ngeo860 [in English].

[6] Brussaard L. (2021) Biodiversity and ecosystem functioning in soil: The dark side of nature and the bright side of life. Ambio 50: 1286-1288. https://doi.org/10.1007/s13280-02101507-z [in English].

[7] Lasota J., Błońska E., Łyszczarz S. \& Tibbett M. (2020) Forest humus type governs heavy metal accumulation in specific organic matter fractions. Water, Air \&Soil Pollution 231: 80. https://doi.org/10.1007/s11270-020-4450-0 [in English].

[8] Kollmann M., Huetteroth W. \& Schachtner J. (2011) Brain organization in Collembola (springtails). Arthropod structure \& development d04-316. https://doi.org/10.1016/j.asd.2011.02.003 [in English].

[9] Sasaki G., Ishiwata K., Machida R., Miyata T. \& Su Z-H. (2013) Molecular phylogenetic analyses support the monophyly of Hexapoda and suggest the paraphyly of Entognatha. BMC Evolutionary Biology 13: 236. https://doi.org/10.1186/1471-2148-13-236 [in English].

[10]Haynes R.J. (2014) Nature of the Belowground Ecosystem and Its Development during Pedogenesis. In: Sparks DL (ed.) Advances in agronomy 127: 43-109. Elsevier Academic Press. https://doi.org/10.1016/B978-0-12-800131-8.00002-9 [in English].

[11] Galli L., Capurro M., Colasanto E., Molyneux T., Murray A., Torti C. \& Zinni M. (2019) A synopsis of the ecology of Protura (Arthropoda: Hexapoda). Revue suisse de Zoologie 126: 155-164. https://doi.org/10.5281/zenodo.3463443 [in English].

[12] Sendra A., Jiménez-Valverde A., Selfa J. \& Reboleira A.S.PS. (2021) Diversity, ecology, distribution and biogeography of Diplura. Insect Conservation and Diversity https://doi.org/10.1111/icad.12480 [in English].

[13] Thayer M.K. (2005) Staphylinidae Latreille, 1802. In: Beutel RG, Leschen RAB (Eds.) Handbook of Zoology. A Natural History of the Phyla of the Animal Kingdom. Volume IV. Arthropoda: Insecta. Coleoptera, Beetles. Volume 1. Morphology and Systematics: 296-344. Walter de Gruyter, Berlin, Germany [in English].

[14]Folgarait P.J. (1998) Ant biodiversity and its relationship to ecosystem functioning: a review. Biodiversity and Conservation 7: 1221-1244. http://dx.doi.org/10.1023/A:1008891901953 [in English].

[15]Perveen F. \& Khan A. (2021) Introductory Chapter: Diptera. In: Perveen F.K. (Ed.) The Wonders of Diptera - Characteristics, Diversity, and Significance for the World's Ecosystems. IntechOpen https://doi.org/10.5772/intechopen.99440 [in English].

[16]Foelix R.F. (2011) Biology of spiders. Third edition. Oxford University Press. 428pp. [in English].

[17] Harvey M.S. (1988) The systematics and biology of pseudoscorpions \& N. W. Heather. Australian Arachnology. Australian Entomological Society, Brisbane: 75-85 [in English].

[18] Coddington J.A. \& Colwell R.K. (2001) Arachnids. In: Levin A.L., Colwell R., Daily G., Lubchenco J., Mooney H.A., Schulze E-D., Tilman G.D. (Eds.) Encyclopedia of Biodiversity. Princeton University, Princeton, New Jersey, USA: 199-218 [in English]. 
[19]Dunlop J.A. \& Penney D. (2011) Order Araneae Clerck, 1757. In: Zhang Z-Q. (ed.) Animal biodiversity: An outline of higher-level classification and survey of taxonomic richness. Zootaxa 3148: 149-153. https://doi.org/10.11646/zootaxa.3148.1.27 [in English].

[20] World Spider Catalog. World Spider Catalog. (2021) Version 22.5. Natural History Museum Bern, online at http://wsc.nmbe.ch, accessed on 22.112021. https://doi.org/10.24436/2 [in English].

[21]Beaulieu F., Dowling A.P.G., Klompen H., de Moraes G.J. \& Walter D.E. (2011) Superorder Parasitiformes Reuter, 1909. In: Zhang Z-Q (Ed.) Animal biodiversity: An outline of higher-level classification and survey of taxonomic richness. Zootaxa 3148: 123-128. https://doi.org/10.11646/zootaxa.3148.1.23 [in English].

[22] Schatz H., Behan-Pelletier V.M., O’Connor B.M. \& Norton R.A. (2011) Suborder Oribatida van der Hammen, 1968. In: Zhang Z-Q (ed.) Animal biodiversity: An outline of higherlevel classification and survey of taxonomic richness. Zootaxa 3148: 141-148. https://doi.org/10.11646/zootaxa.3148.1.26 [in English].

[23] Walter D.E., Bolton S., Uusitalo M. \& Zhang Z-Q. (2011) Suborder Endeostigmata Reuter, 1909. In: Zhang Z-Q (ed.) Animal biodiversity: An outline of higher-level classification and survey of taxonomic richness. Zootaxa 3148: 139-140. https://doi.org/10.11646/zootaxa.3148.1.25 [in English].

[24]Zhang Z-Q., Fan Q-H., Pesic V., et al. (2011) Order Trombidiformes Reuter, 1909. In: Zhang Z-Q (Ed.) Animal biodiversity: An outline of higher-level classification and survey of taxonomic richness. Zootaxa 3148: 129-138. https://doi.org/10.11646/zootaxa.3148.1.24 [in English].

[25] Walter D.E. \& Proctor H. (2013) Mites: ecology, evolution \& behaviour. Life at a microscale. 2nd ed. Dordrecht (The Netherlands): Springer Netherlands, Springer Science+Business Media. 494pp. [in English].

[26]Krantz G.W. \& Walter D.E. (2009) A manual of acarology. 3rd ed. Lubbock (TX): Texas Tech University Press. 807pp. [in English].

[27]Boczek J. \& Błaszak C. (2005) Mites (Acari). Importance in human life and economy. SGGW Warszawa, 267 pp. [in Polish]

[28]Bödeker I.T.M, Lindahl B.D., Olson Å. \& Clemmensen K.E. (2016) Mycorrhizal and saprotrophic fungal guilds compete for the same organic substrates but affect decomposition differently. Functional Ecology 30: 1967-1978. https://doi.org/10.1111/1365-2435.12677 [in English].

[29] Cronberg N., Natcheva R. \& Hedlund K. (2006) Microarthropods mediate sperm transfer in mosses. Science 313: 1255. https://doi.org/10.1126/science.1128707 [in English].

[30]Beaulieu F. \& Walter D. (2007) Predation in suspended and forest floor soils: observations on Australian mesostigmatic mites. Acarologia 47: 43-54. Retrieved from https://www1.montpellier.inra.fr/CBGP/acarologia/article.php?id=16 [in English].

[31] Seniczak S., Graczyk R., Seniczak A., Faleńczyk-Koziróg K., Kaczmarek S. \& Marquardt T. (2018) Microhabitat preferences of Oribatida and Mesostigmata (Acari) inhabiting lowland beech forest in Poland and the trophic interactions between these mites. European Journal of Soil Biology 87: 25-32. https://doi.org/10.1016/j.ejsobi.2018.04.004 [in English].

[32] Kaczmarek S. (2000a). Soil Gamasida (Acari) of the young Scots pine forests within areas affected by pollutants of selected industrial plants. WSP Bydgoszcz. 121 pp. [in Polish]

[33]Peschel K., Norton R.A., Scheu S. \& Maraun M. (2006). Do oribatid mites live in enemy-free space? Evidence from feeding experiments with the predatory mite Pergamasusseptentrionalis. Soil Biology and Biochemistry 38: 2985-2989. https://doi.org/10.1016/j.soilbio.2006.04.035 [in English]. 
[34]Brückner A., Wehner K., Neis M. \&, Heethoff M. (2016) Attack and defense in a gamasid-oribatid mite predator-prey experiment - sclerotization outperforms chemical repellency. Acarologia 56: 451-461. https://doi.org/10.1051/acarologia/20164135 [in English].

[35]Heethoff M., Brückner A., Schmelzle S., et al. (2018). Life as a fortress - structure, function, and adaptive values of morphological and chemical defense in the oribatid mite Euphthiracarusreticulatus (Actinotrichida). BMC Zoology 3: 7. https://doi.org/10.1186/s40850018-0031-8 [in English].

[36] Kheradmand K., Kamali K., Fathipour Y. \& Goltapeh E.M. (2007). Development, life table and thermal requirement of Tyrophagusputrescentiae (Astigmata: Acaridae) on mushrooms. Journal of Stored Products Research 43: 276-281. https://doi.org/10.1016/j.jspr.2006.06.007 [in English].

[37] Jung C. \& Kawashima M. (2010) Artificial ground shelters for overwintering phytoseiid mites in orchards. Experimental and Applied Acarology 52: 35-47. https://doi.org/10.1007/s10493010-9347-y [in English].

[38] Mielke-Ehret N. \& Mühlbach H-P. (2012) Emaravirus: anovel genus of multipartite, negative strand RNA plant viruses. MDPI Viruses 4: 1515-1536. https://doi.org/10.3390/v4091515 [in English].

[39] Choi O., Park J-J. \& Kim J. (2016) Tetranychusurticae (Acari: Tetranychidae) transmits Acidovoraxcitrulli, causal agent of bacterial fruit blotch of watermelon. Experimental and Applied Acarology 69: 445-451. https://doi.org/10.1007/s10493-016-0048-z [in English].

[40]Brunner J.L, Killilea M. \& Ostfeld R.S. (2012) Overwintering survival of nymphal Ixodes scapularis (Acari: Ixodidae) under natural conditions. Journal of Medical Entomology 49: 981-987. https://doi.org/10.1603/ME12060 [in English].

[41]Burtis J.C., Yavitt J.B., Fahley T.J. \& Ostfeld R.S. (2019) Ticks as Soil-Dwelling Arthropods: An Intersection Between Disease and Soil Ecology. Journal of Medical Entomology 56: 1555-1564. https://doi.org/10.1093/jme/tjz1 16 [in English].

[42]Denegri G.M. (1993) Review of oribatid mites as intermediate hosts of tapeworms of the Anoplocephalidae. Experimental and Applied Acarology 17: 567-580. https://doi.org/10.1007/BF00053486 [in English].

[43] Seniczak S., Klimek A., Gackowski G., Kaczmarek S. \& Zalewski W. (1997) Effect of copper smelting air pollution on the mites (Acari) associated with young Scots pine forests polluted by a copper smelting works at Głogów, Poland. Part 2: Soil mites. Water, Air and Soil Pollution 97: 287-302. https://doi.org/10.1023/A:1026423702444 [in English].

[44] Seniczak S., Dąbrowski J., Klimek A. \& Kaczmarek S. (1998) Effects of air pollution produced by a nitrogen fertilizer factory on the mites (Acari) associated with young Scots pine forests in Poland. Applied Soil Ecology 9: 453-458. https://doi.org/10.1016/S0929-1393(98)001048 [in English].

[45] Seniczak S., Dąbrowski J., Klimek A. \& Kaczmarek S. (1999) Effect of alkaline deposition on the mites (Acari) associated with young Scots pine forests in Poland. Water, Air and Soil Pollution 109: 407-428. https://doi.org/10.1023/A:1005050410966 [in English].

[46] Seniczak S, Kaczmarek S, Klimek A. \&, Seniczak A. (2002) The effect of some air pollutants on the vertical distribution of mites (Acari) in soils of young Scots pine forests in Poland. European Journal of Soil Biology 38: 311-314. https://doi.org/10.1016/S1164-5563(02)01165-2 [in English].

[47]Cierzniak T. \&, Kaczmarek S. (2000) Forest islands as refuges: pollinating insects and soil mites. In: Banaszak J (ed.) Ecology of forest islands. Bydgoszcz Academy of Kazimierz Wielki Press, Bydgoszcz, Poland: 223-231. [in English].

[48] Kaczmarek S. \& Marquardt T. (2008) The impact of the diversity of the habitats of the "BagnoStawek" reserve in the Zaborski Landscape Park on the shaping of species diversity of soil 
mites (Acari, Gamasida) (BoryTucholskie). In: Kaczmarek S (ed.) Landscape and biodiversity. Kazimierz Wielki University Press, Bydgoszcz, Poland: 215-227. [in Polish].

[49] Marquardt T., Kaczmarek S., Faleńczyk-Koziróg K. \& Wachowiak E. (2011) The role of marshy habitats in the shaping of species diversity of the soil mites (Acari: Mesostigmata) in the forest recreation area of Osowa Góra in Bydgoszcz (Poland). In: Indykiewicz P (Ed.) Urban fauna: studies of animal biology, ecology and conservation in European cities. University of Technology and Life Sciences Press, Bydgoszcz, Poland: 65-71. [in English].

[50]Manu M., Băncilă R.I., Bîrsan C.C., Mountford O. \& Onet M. (2021) Soil mite communities (Acari: Mesostigmata) as indicators of urban ecosystems in Bucharest, Romania. Nature Scientific Reports 11: 3794. https://doi.org/10.1038/s41598-021-83417-4 [in English].

[51] Huguier P., Manier N., Owojori O.J., Bauda P., Pandard P. \& Römbke J. (2015) The use of soil mites in ecotoxicology: a review. Ecotoxicology 24: 1-18. https://doi.org/10.1007/s10646-014-1363-y [in English].

[52] Kaczmarek S. (2000b) Animal communities of forest islands woodlots: soil mites (Acari). In: Banaszak J (ed.) Ecology of forest islands. Bydgoszcz Academy of Kazimierz Wielki Press, Bydgoszcz, Poland: 91-106 [in English]

[53] Kaczmarek S. (2000c) The role of ecotones in biological exchange with the surroundings, with particular reference to soil mites. In: Banaszak J (Ed.) Ecology of forest islands. Bydgoszcz Academy of Kazimierz Wielki Press, Bydgoszcz, Poland: 253-258. [in English].

[54] Losey J.E. \& Vaughan M. (2006) The economic value of ecological services provided by insects. BioScience 56: 311-323. https://doi.org/10.1641/0006-3568(2006)56[311: TEVOES]2.0.CO;2 [in English].

[55] Hein L. (2009) The economic value of the pollination service, a review across scales. The Open Ecology Journal 2: 74-82. Retrieved from https://doi.org/10.2174 /1874213000902010074 [in English].

[56] Kjøhl M., Nielsen A. \& Stenseth N.C. (2011) Potential effects of climate change on crop pollination. Food and Agriculture Organization of the United Nations, Rome, 38pp. Retrieved from https://www.fao.org/fileadmin/templates/agphome/documents/Biodiversity-pollination/

Climate Pollination 17 web 2 .pdf [in English].

[57] Huguenin M.T., Leggett C.G., Paterson R.W. (2006) Economic valuation of soil fauna. European Journal of Soil Biology 42: S16-S22. https://doi.org/10.1016/j.ejsobi.2006.10.003 [in English].

[58] Jónsson J.Ö. \&, Davíðsdóttir B. (2016) Classification and valuation of soil ecosystem services. Agricultural Systems 145: 24-38. https://doi.org/10.1016/j.agsy.2016.02.010 [in English].

\section{Качмарек С., Марквардт Т.}

ТОПЫРАК МИКРОАРТРОПОДТАРЫ-БИОАЛУАНТУРЛІЛІК, ЭКОЖУЙЕЛІК ҚЫЗМЕТТЕР ЖӘНЕ ЭКОНОМИКА МЕН АДАМ ДЕНСАУЛЫҒЫНА ӘСЕРІ

Андатпа. Топырақ жүйесі жер үсті экожүйелерінің бөлігі ретінде жер бетіндегі биологиялық процестердің үздіксіздігін қамтамасыз ететін маңызды экологиялық процестердің орны болып табылады. Топырақ микроартроподтары пішіні мен қызметі жағынан өте алуан түрлі, топырақтың түріне байланысты және топырақ процестеріне негізінен тамақтану арқылы әсер етеді, осылайша өлі Органикалық заттардың ыдырауына тікелей немесе жанама әсер етеді. Топырақ микроартроподтарының белгілі бір топтары маңызды экожүйелік қызметтерді ұсынады, бірақ олар оң және теріс экологиялық және экономикалық әсер етуі мүмкін. Бұл мақалада топырақтың нақты микроартроподтарының топырақ тамақтану желісіндегі орны және топырақ экожүйесіне, экономика мен адам денсаулығына басқа да бейфикалық емес әсері тұрғысынан рөлі қарастырылады, сонымен қатар топырақ фаунасын практикалық қолдану мүмкіндіктері атап өтіледі.

Кілт сөздер: микроартроподтар, топырақ ортасы, эдафон, топырақтың қоректік торы, органикалық заттардың ыдырауы. 


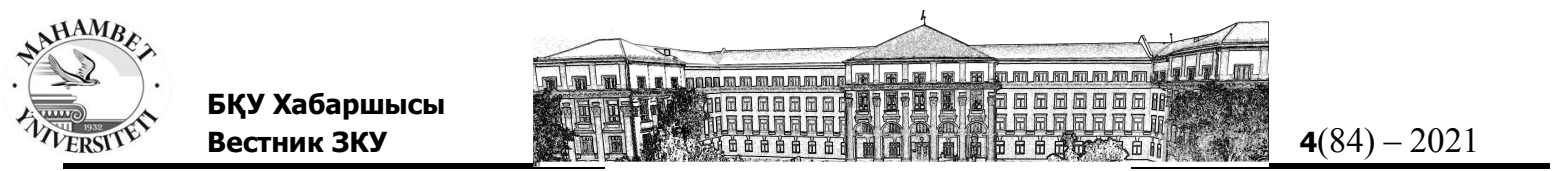

Качмарек С., Марквардт Т.

ПОЧВЕННЫЕ МИКРОАРТРОПОДЫ - БИОРАЗНООБРАЗИЕ, ЭКОСИСТЕМНЫЕ УСЛУГИ И ВЛИЯНИЕ НА ЭКОНОМИКУ И ЗДОРОВЬЕ ЧЕЛОВЕКА

Аннотация. Почвенная система, как часть наземных экосистем, является местом важнейших экологических процессов, которые обеспечивают непрерывность биологических процессов на Земле. Почвенные микроартроподы очень разнообразны по форме и функциям, зависят от типа почвы и влияют на почвенные процессы главным образом через питание, тем самым прямо или косвенно влияя на разложение мертвого органического вещества. Определенные группы почвенных микроартропод обеспечивают важные экосистемные услуги, однако могут оказывать как положительное, так и отрицательное экологическое и экономическое воздействие. В этой статье рассмотрена роль конкретных почвенных микроартропод в контексте их положения в почвенной пищевой сети и других нетрофических влияний на почвенную экосистему, экономику и здоровье человека, а также подчеркнуты возможности практического использования почвенной фауны.

Ключевые слова: микроартроподы, почвенная среда, эдафон, почвенная трофическая сеть, разложение органического вещества. 